\title{
SOCIAL ENTREPRENEURSHIP AND SOCIAL INEQUALITY: A CASE STUDY OF LATVIA
}

Aija Sannikova1, Dr. oec. /assistant professor/ senior researcher; Jelena Titko², Dr.oec. / professor

${ }^{1}$ EKA University of Applied Sciences; BSA University of Applied Sciences, ${ }^{2}$ EKA University of Applied Sciences

\begin{abstract}
The present research analyses the theoretical and practical aspects of interaction between social entrepreneurship and socio-economic processes, thereby building up scientific experience in analyses of social entrepreneurship processes. The authors, based on a theoretical literature review and an examination of social entrepreneurship in Latvia, analysed the elements of the social entrepreneurship ecosystem, the impacts of social entrepreneurship and statistical data on social inequality in Latvia. The research concluded that social development in Latvia was at the initial stage, yet it provided support to people at risk of social exclusion and poverty. The development of social entrepreneurship in the regions of Latvia was uneven.
\end{abstract}

Key words: income inequality, social entrepreneurship, region, poverty

JEL code: L31, R58, I32, C31

\section{Introduction}

Although social entrepreneurship is a widely known kind of entrepreneurship in the world, in Latvia its development has been seen only for the third year, as the Social Enterprise Law became effective on 1 April 2018. The problem is that the aspects of social entrepreneurship have so far been little researched in Latvia. A hypothesis put forward by the authors is as follows: social entrepreneurship makes a positive qualitative effect on the reduction of regional disparities in poverty and social exclusion in Latvia, yet the effect is not the same across the regions. The research aims to analyse the role of social entrepreneurship in Latvia in reducing poverty and social exclusion. The specific tasks of the research are as follows: 1) to analyse changes in the foundation of social enterprises and the areas of their social impacts in Latvia; 2) to analyse the aspects of disparities in poverty and social exclusion and the relevant data on Latvia. Limitations of the research: the areas of social impacts made by social enterprises in Latvia were identified analysing relevant documents -the information specified in the applications for social enterprise status. The research did not analyse the business aspects of social enterprise development. Research methods: theoretical literature review, documentary analysis to identify social enterprises in Latvia in the period 2018-2021, statistical analysis to perform the specific research tasks.

\section{Research results and discussion}

\section{Role of social entrepreneurship in society}

Social justice forms the basis of social policy, and its main objective is to maintain the standard of living and reduce inequalities (Rajevska, 2014). Social entrepreneurship could be defined as an innovative social value-generating activity that is performed in the non-profit, business or government sectors (Austin, Stevenson, Wei-Skillern, 2006). In Latvia in accordance with the relevant regulatory framework, social enterprises are limited liability companies (Saeima, 2017). Social enterprises are the driver of change (Lukjanska, Kuznecova, Cirule, 2017). However, the problem is that there is a lack of convincing evidence that the role of social enterprises in dealing with global challenges is crucial; on the contrary, there is some evidence that the problems identified diminish if multiple agents are involved, such as NGOs, municipalities, public-private partnership agents (Kirsch, 2011).

1 E-mail: aija.sannikova@inbox.Iv, Tel: (+371) 25155419 
Combining the logic of classical business with social impacts is one of the features of social entrepreneurship and an important instrument for the socio-economic development of the region. The role of social enterprises in the development of regions could be examined from various perspectives (Light, 2010; Social Entrepreneurship Association of Latvia, 2019a; Arhipova, 2020; Haues, Boyle, 2021), yet social entrepreneurship as part of the single social ecosystem makes a direct and indirect contribution to dealing with factors hindering the development of society, e.g. poverty reduction (Chee, 2004). Each ecosystem entity influences the others by establishing ever-changing relationships in which each entity should be flexible and adaptable.

Social entrepreneurship as a new economic category finds its opportunities for development between market imperfections and available resources (Dees, 1998). Social enterprises participate in generating social value and regard it as their mission, therefore, the multifaceted nature of their activities and socioeconomic impacts should be assessed (Alvord, Brown, Letts, 2003, 2004). However, in economic reality, social enterprises often focus too much on reducing social problems (Dees, 1998; Austin, Stevenson, WeiSkillern, 2006), which makes a negative effect on the capability of social enterprises to attract competitive human resources or to mobilize resources.

Social entrepreneurship choices could be affected by market imperfections and exogenous and endogenous factors (European Union/OECD, 2016). The endogenous factors include an enterprise's management's experience and ability to understand socio-economic processes, networking and resource acquisition skills, the desire to make a creative social impact on change in the region. The European Union (European Union, 2020) points out that it is very important for social entrepreneurs to learn and develop their own skills. However, the exogenous factors, such as public contract availability, special marks or labels, public support - campaigns, recognition, awards - can promote and popularize the mission of social enterprises.

\section{Social entrepreneurship ecosystem and activities in Latvia}

It is widely acknowledged that social entrepreneurship transforms society and promotes positive changes in regions, yet it is difficult to assess the individual role of a particular factor or intervention agent in the processes, especially because geographically regions are usually open spatial units in contrast to countries (Nijkam p, Abreu, 2009). Therefore, the activities of social enterprises within their ecosystems are often a focus for researchers.

The authors, based on a theoretical literature review (European Union, 2020; Pratono, Sutanti, 2016; Kim, Lee, Roh, Son, 2020; Social Entrepreneurship Association of Latvia, 2019b; Penwick, 2011; Babson Global, 2017; Saeima of the Republic of Latvia, 2017; Cabinet of the Republic of Latvia, 2018a, 2018b; Ministry of Welfare of the Republic of Latvia, 2020a, 2020b; Bærenholdt, 2009) and research studies on social entrepreneurship in Latvia, concluded that social entrepreneurship was carried out in a complex ecosystem, and it depended on each country's regulatory framework, political support, socio-economic situation in the regions and demographic trends as well as other exogenous factors. However, the development of social entrepreneurship was affected by available resources, which were exploited within the strategy chosen and components promoting socio-economic development by employing market imperfections (Figure 1). 


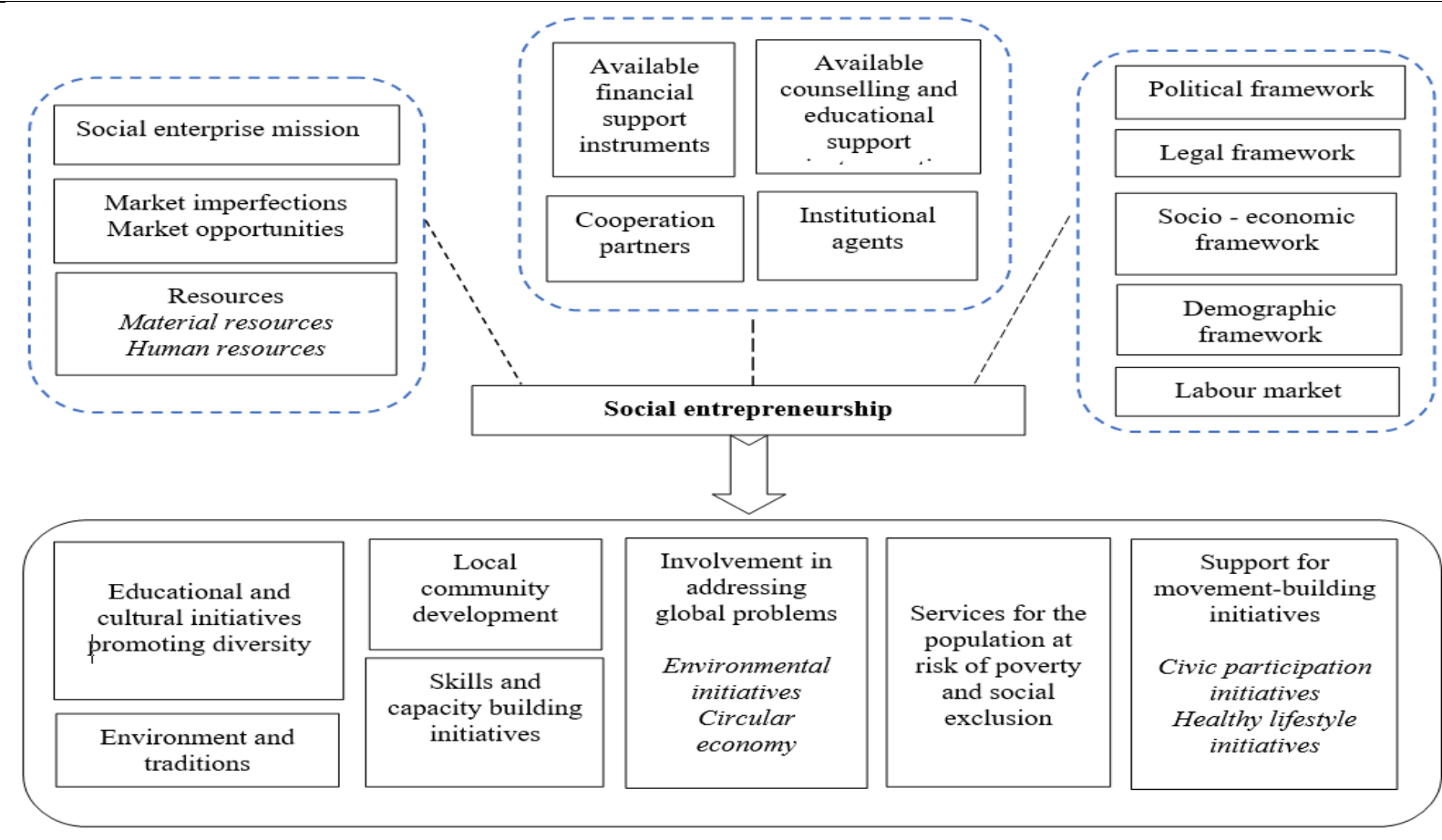

\section{Source: authors' construction}

Fig. 1. Social entrepreneurship ecosystem and the impacts

In Latvia, ESF funding could be used to prepare economic entities for obtaining social enterprise status, and ESF project No. 9.1.1.3/15/I/001 "Support for social entrepreneurship" (Ministry of Welfare of the Republic of Latvia, 2020b) was launched and support for the introduction of social measures and the transition to social enterprise status was provided. Initially, the enterprises involved in the preparatory process were called measure participants. At the end of 2018, 98 enterprises or measure participants and 28 social enterprises were registered with the Ministry of Welfare of the Republic of Latvia.

The authors' analysis revealed that from the very beginning, the dominant field of impacts of social enterprises was support for persons at risk of social exclusion and poverty - in 2018, 26 \% participants and $37 \%$ social enterprises provided such direct employment support (Figure 2).

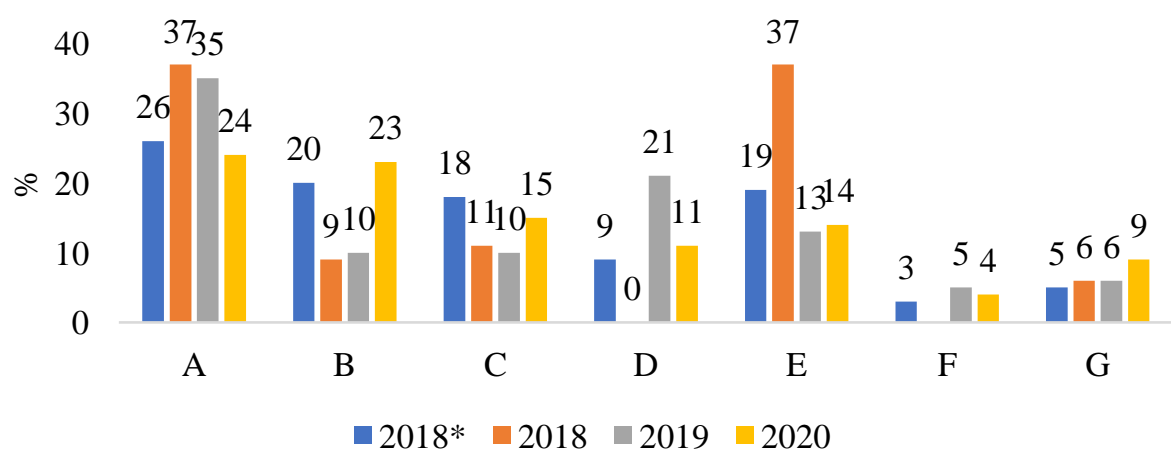

Notes: data at the end of the calendar year; 2018* - participants - NGOs and enterprises that were registered before the adoption of the Social Enterprise Law; 2018 - enterprises registered in accordance with the Social Enterprise Law (Saeima of the Republic of Latvia a, 2017), A-work integration; B- education; C-sports and health promotion; D- civic society and cultural diversity; E- social services and support for people at risk of poverty and social exclusion, $F$ environmental protection; G- other services

Source: authors' construction based on social entrepreneurship research documents in Latvia

Fig. 2. Fields for social entrepreneurship in Latvia in the period 2018-2020

Over the next years in Latvia, the main target groups for social entrepreneurship were vulnerable groups (Cabinet of the Republic of Latvia, 2018b) - persons with disabilities, the unemployed and persons at risk 
of poverty. The authors concluded that socially vulnerable groups were provided with employment support and free services or services at a reduced price (Figure 2). However, also indirect support was provided, for example, through involving the target groups in educational activities, sporting events or community service activities in order to reduce their social exclusion.

The social and economic significance of the social entrepreneurship mission in Latvia is indicated by the fact that the number of social enterprises increased - at the end of 2019, 81 economically active social enterprises were registered in Latvia, while in February 2021 their number increased to 161 (Ministry of Welfare, 2021). However, there were also some problems, as not all the social enterprises were able to combine business expansion with social impact. This is evidenced by the fact that: 1) in the period 2018-2021, 56 enterprises were not granted social enterprise status because the enterprises were not able to prove the sustainability of their activity and the significance of their social impact; 2 ) $8.5 \%$ enterprises were deprived of social enterprise status or they renounced it - the reason was the inability to carry out commercial activities under the current socio-economic conditions.

The regional impacts of social enterprises are difficult to identify, as often the enterprises' business and social impacts are made within several regions. Therefore, the place of registration of social enterprise activities was analysed at this stage of the research. The authors concluded that in 2019, there were 49 economically active enterprises in Riga region, 14 in Pieriga region, 8 in Kurzeme region, 6 in Zemgale region, 3 in Vidzeme region and one in Latgale region. To identify whether there was a difference between the total number of economically active enterprises (CSB, 2020a) and the number of social enterprises in the regions of Latvia in 2019, a Wilcoxon signed ranks test was performed by the authors. The results showed (Figure 3 ) that one could reject the $\mathrm{HO}$ hypothesis at the $95 \%$ confidence level: economic activity was the same for both groups and accept the $\mathrm{H} 1$ hypothesis: economic activity was different. This indicated that social entrepreneurship was carried out in an ecosystem where there were also factors that significantly affected the development of social entrepreneurship.

\begin{tabular}{|c|c|c|c|c|}
\hline \multicolumn{5}{|c|}{ Ranks } \\
\hline & & $\mathrm{N}$ & Mean Rank & Sum of Ranks \\
\hline \multirow[t]{4}{*}{$\mathrm{SR}-\mathrm{AR}$} & Negative Ranks & $6^{\mathrm{a}}$ & 3,50 & 21,00 \\
\hline & Positive Ranks & $0^{\mathrm{b}}$ &, 00 &, 00 \\
\hline & Ties & $0^{c}$ & & \\
\hline & Total & 6 & & \\
\hline
\end{tabular}

\begin{tabular}{|c|c|}
\hline \multicolumn{2}{|l|}{ Test Statistics* } \\
\hline & SR - AR \\
\hline Z & $-2,201^{b}$ \\
\hline Asymp. Sig. (2-tailed) &, 028 \\
\hline
\end{tabular}

Notes: SR- active social enterprises in the regions, AR-all active economic enterprises in the regions Source: authors' calculation using SPSS 26

Fig. 3. Wilcoxon signed ranks test results on the comparison of economic activity across the regions of Latvia in 2019

The minimum income level (MIL) is the income a person needs to be able to live physically and is equal to 40 percent of the median household disposable income. The largest proportion of the population whose income was below the minimum income level was the non-working age population - in 2019, such persons aged 18-64 accounted for $23.6 \%$ of the total group. 
Population below the guaranteed minimum income level and changes in the population in 2010 and 2019 in Latvia nationally and regionally

\begin{tabular}{|c|c|c|c|c|c|c|c|c|}
\hline \multirow{3}{*}{ No } & \multirow{3}{*}{ Region } & \multicolumn{6}{|c|}{ Population below the guaranteed minimum income level } & \multirow{3}{*}{$\begin{array}{c}\text { Population } \\
\text { change, } \\
2019 / \\
2010 \text {, \% }\end{array}$} \\
\hline & & \multicolumn{2}{|c|}{2010} & \multicolumn{2}{|c|}{2019} & \multicolumn{2}{|c|}{$2019 / 2010$} & \\
\hline & & $\begin{array}{c}\text { Number, } \\
\text { thou. }\end{array}$ & $\%$ & $\begin{array}{c}\text { Number, } \\
\text { thou. }\end{array}$ & $\%$ & $\begin{array}{c}\text { Number, } \\
\text { thou. }\end{array}$ & $\begin{array}{l}\text { Percentage } \\
\text { points }\end{array}$ & \\
\hline 1. & Latvia & 207.8 & 9.8 & 149.7 & 7.8 & -58.1 & -2.0 & -10.0 \\
\hline 2. & Riga region & 37.6 & 5.6 & 26.0 & 4.1 & -11.6 & -1.5 & -6.1 \\
\hline 3. & Pieriga region & 26.8 & 7.2 & 20.9 & 5.6 & -5.9 & -1.6 & -0.9 \\
\hline 4. & Vidzeme region & 31.0 & 14.2 & 20.3 & 10.9 & -10.7 & -3.3 & -14.7 \\
\hline 5. & Kurzeme region & 30.4 & 10.9 & 22.4 & 9.3 & -8.0 & -1.6 & -14.0 \\
\hline 6. & Zemgale region & 36.6 & 14.0 & 19.4 & 8.4 & -17.2 & -5.6 & -11.9 \\
\hline 7. & Latgale region & 45.4 & 14.5 & 40.7 & 15.6 & -4.7 & 1.1 & -17.1 \\
\hline
\end{tabular}

Notes: 2019/2010 - changes in 2019 compared with 2010

\section{Source: author's calculations based on CSB, 2021a, 2021b}

However, employment did not always provide enough income: in 2019, $2.4 \%$ of total working-age employees and $0.2 \%$ over working-age employees earned incomes below the minimum income level (CSB, 2020b; 2020c). In reality, however, the incomes of many households were much lower than the minimum income level, and it was even lower than the guaranteed minimum income level (GMI) (Table 1). Therefore, the government sets the guaranteed minimum income level, which is to be provided to every inhabitant of Latvia in accordance with the procedures specified in the relevant regulatory enactments (Darzina, 2019; Cabinet of the Republic of Latvia 2020). The amount of GMI increased over time: in 2020 it was EUR 64 per person per month, yet from 2021 the minimum income threshold for the first (or main) person in the family was EUR 109, while for each subsequent family member - EUR 76 (Ministry of Welfare of the Republic of Latvia, 2021).

The data analysis showed that in $2019,149.7$ thousand people ( $7.8 \%$ of the total population) in Latvia earned below the GMI. The largest number of people exposed to deep poverty was in Latgale region 40.7 thousand inhabitants ( $15.6 \%$ of the region's population), whereas the smallest number was reported in Riga region with 26.0 thousand inhabitants $(4.1 \%)$. Although the number of people earning below the guaranteed minimum income level in all the regions of Latvia in 2019 was lower than in 2010, it is not only the result of social policies, and it was also influenced by negative demographic changes - the population decline and an increase in old-age pension recipients (CSB, 2020d). However, social inequality can also be a stimulus, as income inequality in the regions increases the opportunity for individuals to engage in social entrepreneurship, incl. to establish social enterprises (Pathak, Muralidharan, 2017) or respond to the offer of social enterprises to become participants in specific support measures.

\section{Conclusions, proposals, recommendations}

1) In Latvia, social entrepreneurship develops within a complex ecosystem, and in the regions of Latvia in the period 2018-2020 its development was uneven - the largest number of social enterprises was registered in Riga region, whereas the smallest number - in Latgale region. The study proves that social entrepreneurship makes a positive qualitative effect on the reduction of regional disparities in poverty and social exclusion in Latvia, yet the effect is not the same across the regions. 
2) In Latvia, the reduction of social inequality could be achieved through complex business solutions - locally and regionally innovative solutions for ensuring employment and access to services for groups at risk of social exclusion and poverty. The analysis showed that the measures were aimed at the education of the target groups, their involvement in sports activities and a healthy lifestyle, as well as the support provided in the field of health promotion.

3) Social enterprises in Latvia should perform a dual activity - business activities that yield a profit and activities making a social impact. Both the relevant theoretical literature and practices recognize that this is one of the most significant challenges to the long-term existence of social enterprises.

4) The number of population at risk of social exclusion and poverty in a region makes a little effect on the development of social entrepreneurship, and the proof of this fact was that in Latgale region with the largest population earning below the GMI, the number of social enterprises was the smallest. Therefore, future research studies should identify the factors influencing the development of social entrepreneurship in the regions.

\section{Bibliography}

1. Alvord, S. H., Brown, L. D., Letts, C. W. (2004). Social Entrepreneurship and Social Transformation: An Exploratory Study (Working Paper No. 15). Cambridge, MA: The Hauser Center for Nonprofit Organizations and The Kennedy School of Government, Harvard Retrieved: University. https://doi.org/10.1177/0021886304266847; https://journals.sagepub.com/doi/pdf/10.1177/0021886304266847. Access: 11.01.2021.

2. Alvord, S.H., Brown, L.D., Letts, C.W. (2003). Social Entrepreneurship Leadership that Facilitates Societal Transformations - an Exploratory Study. Retrieved: https://dspace.mit.edu/bitstream/handle/1721.1/55803/CPL_WP_03_5_AlvordBrownLetts.pdf?sequence=1\&isAl lowed=y. Access: 24.02. 2021.

3. Arhipova, I. (2020). Ekosistemu pakalpojumu ekonomiska novertesana. Vide un politika (Economic Assessment of Ecosystem Services. The Environment and Policies). Retrieved: https://www.zemeunvalsts.Iv/vide-unpolitika Access: 04.03. 2021.

4. Austin, J., Stevenson, H., Wei-Skillern, J. (2006). Social and Commercial Entrepreneurship: Same, Different or both? Entrepreneurship Theory and Practice, 30, 1-22. Retrieved: https://www.sciencedirect.com/science/article/pii/S0080210716302357 Retrieved: https://www.researchgate.net/publication/228263352_Social_and_Commercial_Entrepreneurship_Same_Differ ent_or_Both Access: 17.10.2020.

5. Bærenholdt, J.O. (2009). Regional Development and Noneconomic Factors. International Encyclopedia of Human Geography, 2009, Pages 181-186. Retrieved: https://www.sciencedirect.com/science/article/pii/B978008044910400866X Access: 20.02. 2021.

6. Babson Global (2017). The 6 Domains of the Entrepreneurship Ecosystem: Part Four - FINANCE. Int'l Strategic Mgmt. Retrieved: https://medium.com/@myISMinc/the-6-domains-of-the-entrepreneurship-ecosystem-partfour-finance-3eca6f6f268f

7. Dees, J., G. (1998). The Meaning of Social Entrepreneurship. https://centers.fuqua.duke.edu/case/wpRetrieved: content/uploads/sites/7/2015/03/Article_Dees_MeaningofSocialEntrepreneurship_2001.pdf Access: 21.11.2020.

8. Darzina, L. (2019). GMI limenis un pabalsts. Cik, kam un kad to maksa? LV: Cilveks, valsts, likums (GMI Level and Benefit. How Much, to Whom and When is it Paid? LV: Man, the State, Law). Retrieved: https://lvportals.Iv/skaidrojumi/309269-gmi-limenis-un-pabalsts-cik-kam-un-kad-to-maksa-2019. Access: 27.02.2021.

9. Cabinet of the Republic of Latvia (2020). LR Ministru kabineta 2020. gada 17. decembra noteikumi Nr. 809 "Noteikumi par majsaimniecibas materialas situacijas izvertesanu un socialas palidzibas sanemsanu". (Cabinet Regulation No. 809 of 17 December 2020 Regulations regarding the Assessment of the Material Situation of the Household and Receipt of Social Assistance.) Retrieved: https://likumi.Iv/ta/id/319717-noteikumi-parmajsaimniecibas-materialas-situacijas-izvertesanu-un-socialas-palidzibas-sanemsanu. Access: 02. 03.2021.

10. Cabinet of the Republic of Latvia (2018a). Ministru kabineta 2018. gada 3. aprila noteikumi Nr. 197 "Noteikumi par komercdarbibas atbalsta pieskirsanas nosacijumiem socialajiem uznemumiem un atbalsta pieskirsanas kartibu" (Cabinet of the Republic of Latvia (2018). Regulations of the Cabinet of Ministers No. 197 "Regulations on the Conditions for Granting Business Support to Social Enterprises and the Procedure for Granting Support"). https://likumi.lv/ta/id/298162

11. Cabinet of the Republic of Latvia (2018b). Ministru kabineta 2018. gada 27. marta noteikumi Nr.173 "Noteikumi par socialas atstumtibas riskam paklauto iedzivotaju grupam un sociala uznemuma statusa pieskirsanas, registresanas un uzraudzibas kartibu" (Cabinet of the Republic of Latvia (2018). Cabinet Regulation No. 173 of 27 March 2018 Regulations Regarding the Procedures for Granting, Registration and Supervision of the Status of the Population at Risk of Social Exclusion and Social Enterprise). Retrieved: 2021.https://likumi.lv/ta/id/298035 Access: 17.01.2021. 
12. Chee, Y., E. (2004). An Ecological Perspective on the Valuation of Ecosystem Services. School of Botany, The University of Melbourne, Parkville, Vic. 3010, Australia. Retrieved:

https://archive.epa.gov/nheerl/arm/web/pdf/chee2004.pdf Access: 04.03.2021.

13. CSB (2021a). ISG020. Population Number and its change by Statistical Region, City, Town, 21 Development Centres and County. Retrieved: http://data1.csb.gov.Iv/pxweb/en/iedz/iedz_iedzskaits_ikgad/ISG020.px/ Access: 01.03.2021.

14. CSB (2021b). NNM020. Share of Persons under Minimum Income Level by Regions (\%) by Territorial unit and Time Period. Retrieved: https://data.stat.gov.Iv/pxweb/en/OSP_PUB/START_POP_NN_NNM/NNM020/ Access: 01.03.2021.

15. CSB (2020a). Enterprises. Number of Enterprises. SRG010. Economically Active Enterprises in Statistical Regions, Cities under State Jurisdiction and Counties. Retrieved: http://data1.csb.gov.Iv/pxweb/en/uzn/uzn_01_skaits/SRG010.px/ Access: 13.01.2021.

16. CSB (2020b). MIG010. Minimum Income Level (illustrative values), euro per month. Retrieved: http://data1.csb.gov.Iv/pxweb/en/sociala/sociala_nabadz_nevienl_min_ien/MIG010.px/table/tableViewLayou t1/ Access: 11.12.2020.

17. CSB (2020c). MIG040. Share of Persons under Minimum Income Level by Most Frequent Activity, gender and age (\%). Retrieved: http://data1.csb.gov.Iv/pxweb/en/sociala/sociala_nabadz_nevienl_min_ien/MIG040.px/ Access: 11.12.2020.

18. CSB (2020d). Social Processes. Social Security. Pensions and Benefits. SDG040. Number of Pension Recipients by Average Size of Pension Granted. Retrieved: http://data1.csb.gov.Iv/pxweb/en/sociala/sociala_socdr_pensijas_ikgad/SDG040.px/table/tableViewLayout1 / Access: 07.12.2020.

19. CSB (2021). ISG020. Population Number and its Change by Statistical Region, City, Town, 21 Development Centres and County. Retrieved: http://data1.csb.gov.Iv/pxweb/en/iedz/iedz_iedzskaits_ikgad/ISG020.px/ Access: 07.12.2020.

20. Dees, J., G. (1998). The Meaning of Social Entrepreneurship. Retrieved: https://centers.fuqua.duke.edu/case/wpcontent/uploads/sites/7/2015/03/Article_Dees_MeaningofSocialEntrepreneurship_2001.pdf Access: 28.02.2021.

21. European Union/OECD (2016). Policy Brief on Scaling the Impact of Social Enterprises. Policies for Social Entrepreneurship. Retrieved: https://www.oecd.org/cfe/leed/Policy-brief-Scaling-up-social-enterprises-EN.pdf Access: 14.12.2020.

22. European Union (2020). Social Enterprises and their Ecosystems in Europe. Comparative Synthesis Report. Retrieved:

file://C:/Users/Aija/Downloads/Social\%20enterprises\%20and\%20their\%20ecosystems\%20in\%20Europe.\%20 Comparative\%20synthesis\%20report\%20(1).pdf Access: 02.03.2021.

23. Kirsch, V. (2011). Who Are the Change Makers? Stanford Social Innovation Review. Retrieved: https://ssir.org/books/reviews/entry/driving_social_change_paul_c_light Access: 15.12.2020.

24. Kim, M.G., Lee, J., Roh, T., Son, H. (2020). Social Entrepreneurship Education as an Innovation Hub for Building an Entrepreneurial Ecosystem: The Case of the KAIST Social Entrepreneurship MBA Program. Sustainability, MDPI, Open Access Journal, vol. 12(22), pages 1-23, November. DOI: 10.3390/su12229736 R: file://C:/Users/Aija/Downloads/sustainability-12-09736-v2.pdf

25. Light, P.C. (2010). Driving Social Change: How to Solve the World's Toughest Problems. Hardcover - December 28, 2010. Retrieved: https://www.amazon.com/Driving-Social-Change-Toughest-Problems/dp/0470922419 Access: 12.12.2020.

26. Lukjanska, R., Kuznecova, J., Cirule, I., (2017). The Development of Social Entrepreneurship in Latvia: the Role of Municipalities. International Journal of Business and Globalisation, Inderscience Enterprises Ltd, vol. 18(3), pages 318-336. Retrieved: http://www.inderscience.com/link.php?id=83206. Access: 12.12.2020.

27. Ministry of Welfare of the Republic of Latvia (2020a). Sociala uznemejdarbiba (Social Entrepreneurship). Retrieved: https://www.Im.gov.Iv/lv/sociala-uznemejdarbiba Access: 30.012021.

28. Ministry of Welfare of the Republic of Latvia (2020b). ESF projekts Nr. 9.1.1.3/15/I/001 „Atbalsts socialajai uznemejdarbibai"(ESF project no. 9.1.1.3/15/I/001 "Support for social entrepreneurship"). Retrieved: https://www.Im.gov.Iv/lv/par-projektu-0

29. Ministry of Welfare of the Republic of Latvia (2021). Retrieved: Register of social enterprises. https://www.Im.gov.Iv/lv/socialo-uznemumu-registrs. Access: 05.03.2021.

30. Nijkamp, P., Abreu, M., A. (2009). Regional Development Theory. Research Memorandum; No. 2009-29. Retrieved: https://www.researchgate.net/publication/254405903_Regional_Development_Theory Access: 02.10.2020.

31. Pathak, S., Muralidharan, E. (2017). Economic Inequality and Social Entrepreneurship. Business \& Society. Business \& Society. Retrieved: https://doi.org/10.1177/0007650317696069 Access: 17.10.2020.

32. Penwick, N. (2011). Define Your Social Ecosystem. Retrieved: https://go.forrester.com/blogs/11-09-02define_your_social_ecosystem/ Access: 17.10.2020.

33. Pratono, A., H., Sutanti, A. (2016). The Ecosystem of Social Enterprise: Social Culture, Legal Framework, and Policy Review in Indonesia. Pacific Science Review B: Humanities and Social Sciences. Volume 2, Issue 3, November 2016, Pages 106-112. Retrieved: https://www.sciencedirect.com/science/article/pii/S2405883116300338 Access: 17.10.2020. 
34. Saeima of the Republic of Latvia (2017). Sociala uznemuma likums (Social Enterprise Law). Retrieved: https://likumi.Iv/ta/id/294484-sociala-uznemuma-likums. Access: 13.02. 2021.

35. Social Entrepreneurship Association of Latvia (2019a). Pirmais gads ar Sociala uznemuma likumu - secinajumi (The first year with the Social Enterprise Law - conclusions). Retrieved: https://sua.Iv/pirmais-gads-ar-socialauznemuma-likumu-secinajumi/ Access: 23.11.2020.

36. Social Entrepreneurship Association of Latvia (2019b). Sociala uznemejdarbiba Latvija: ricibas plans socialas uznemejdarbibas ekosistemas attistibai (Social Entrepreneurship in Latvia: An Action Plan for the Development of the Social Entrepreneurship Ecosystem). Retrieved: https://sua.lv/wpcontent/uploads/2019/04/LSUA_r\%C4\%ABc\%C4\%ABbas-pl\%C4\%81ns-2.pdf Access: 23.11.2020.

37. Rajevska, O. (2014). Socialais taisnigums un sociala nevienlidziba socialas politikas dizaina (Equity and Social Inequality in Social Policy Design). University of Latvia. Latvijas iedzivotaju identitates un vienlidzibas vertibas (Identity and Equality Values of the Population of Latvia), pp. 113-137. Publisher: University of Latvia. Retrieved:

https://www.researchgate.net/publication/282862723_Socialais_taisnigums_un_sociala_nevienlidziba_socialas _politikas_dizaina_Equity_and_Social_Inequality_in_Social_Policy_Design. Access: 29.11.2020. 